\title{
Evaluation of ecosystem services of two wetland sites on the Wild Coast of South Africa
}

\author{
Q. L. Ndlazi ${ }^{1,2}$, C. M. Musampa ${ }^{1}$, M. D. V. Nakin ${ }^{2}$ \\ \& B. Longo-Mbenza ${ }^{2}$ \\ ${ }^{1}$ Department of Biological and Environmental Sciences, \\ Walter Sisulu University, South Africa \\ ${ }^{2}$ Risk and Vulnerability Science Centre, \\ Walter Sisulu University, South Africa
}

\begin{abstract}
Wetlands provide important and diverse benefits to people around the world, contributing provisioning, regulating, habitat, and cultural services. Wetlands in South Africa are under pressure from drainage, clearance for cultivation, and encroachment of invasive plants. The aim of this study was to assess ecosystem services in Mngazi and Mdumbi wetland sites. In Mdumbi site, two areas were identified while four areas were identified in Mngazi site based on hydrogeomorphic units (HGM). A WET-Eco Services Tool was used to assess goods and services in each wetland site. Questionnaires were also used to solicit the perceptions of communities on wetland impacts. Results revealed that the wetland systems in the lower reaches of Mngazi and Mdumbi Rivers do render a series of services varying from one system to another depending on the size and type of hydrogeomorphic unit. High confidence rating was revealed in provision of natural resources and erosion control in all the wetlands of each site while moderate confidence rating was revealed for provision of erosion control, phosphate trapping, toxicant removal and nitrate removal. Low confidence rating was observed by carbon storage, cultural significance, education, tourism and recreation. The stream flow regulation, sediment trapping, maintenance of biodiversity and sediment trapping varied among wetlands with no clear pattern. In contrary, the majority of respondents perceived the wetlands as bad environments for crime and disasters. These results highlight a need for awareness on ecological importance of wetlands for their effective management.

Keywords: hydrogeomorphic units, wet-ecosystem services. wetland value, Mngazi, Mdumbi.
\end{abstract}




\section{Introduction}

Wetlands are defined by the National Water Act 36 of 1998 as land which is transitional between terrestrial and aquatic systems where the water table is usually at or near the surface or land that is periodically covered with shallow water and usually inhabited by hydrophilic vegetation. Davis [1] broadly defines wetlands as "areas of marsh, fen, peat land or water, whether natural or artificial, permanent or temporary, with water that is static or flowing, fresh, brackish or salt, including areas of marine water, the depth in which at low tide does not exceed six metres".

Coastal wetlands include salt marshes and fresh water or brackish wetlands contiguous to salt marshes, as well as areas of open water within the coastal belt are all considered as parts of a wetland. Salt marshes are areas regularly inundated by salt water through either natural or artificial water courses and where one or more of the hydrophytes exist [2]. Wetlands are considered valuable because they clean the water, recharge water supplies to underground water, reduce flood risks, provide wildlife habitat and provide recreational opportunities such as hunting, camping, and fishing [3]. Other noteworthy benefits derived from the wetlands by the neighboring communities include the provision of grazing, source of water for abstraction, the production of fiber and animal protein, and cultivation, though limited, of some food crops [4]. These ecosystems thus offer a sense of beauty and comfort to those who spend time in the natural areas through sounds, sights, and even smell [5].

However, it is also crucial to note that, wetlands can produce negative externalities such as odours, insects, animal annoyances etc. [3]. In view of the above socio-economic, aesthetic, and ecological benefits of wetlands to the communities, the rate at which they are destroyed is a reason of concern. By 2000, Mitsch and Gosselink [5] had observed that, in the eastern part of South Africa; approximately $50 \%$ of the wetland systems had either been lost or severely degraded. Mitsch and Gosselink [5] blamed this situation on commercial and subsistence agriculture. Begg [6] predicted even greater consequences of ecological degradation, imbalance in the ecosystems and even results to flooding. This is particularly true in South Africa as it is water-scarce [5].

Wetland resources are often under-appreciated resulting in inadequately managed, ineffectively exploited and poor wetland integrity [7]. Our understanding of wetlands and how to manage them has increased significantly in recent years [8]. In South Africa this has been supported by the completion of significant wetland classification projects such as the National Wetlands Inventory project and the National Spatial Biodiversity Assessment which provides an estimate of wetlands condition. This information formed a basis for the National Freshwater Ecosystems Priority Areas [9] atlas and provides the basis for wetland ecosystem status assessments including health and integrity as well as the vulnerability for the purpose of effective ecological and management implementation [9-12].

Climate change is predicted to be a major hazard to the endurance of species and integrity of ecosystems worldwide [13]. Global climate change, a further 
consequence of human activity, is bringing about changes in regional and local climate. Every place on earth now faces changes in the magnitude, timing, frequency, and duration of atmosphere human induced conditions from changes in seasonal temperatures and weather patterns to changes in the temperature and $\mathrm{pH}$ of our oceans [14].

The paucity of baseline data for rural wetland ecosystems still persist on the Wild Coast of South Africa, similarly to many more other wetlands in the region. The aim of this study was to determine the services rendered by the wetlands on the Eastern Cape coast of South Africa. This study will help informed decision making and highlight better management strategies that can be utilized to protect rural coastal wetlands from further degradation.

\section{Methods and materials}

\subsection{Study area}

The Mngazi wetland sites are located approximately 18km south of Port St John's on the east coast of South Africa in the Eastern Cape Province. The wetlands are located on the lower reaches of Mngazi River. The wetlands existing on the following co-ordinates: Site one (31 $\left.{ }^{\circ} 40^{\prime} 04 \mathrm{~S}, 2^{\circ} 27^{\prime} 36 \mathrm{E}\right)$, Site two (31 $40^{\prime} 01$

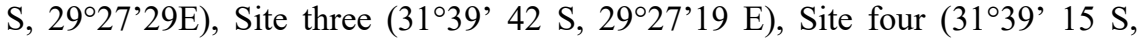
29॰27’39 E).

The Mdumbi wetland sites are located on the lower reaches of Mdumbi River in close proximity to the Mdumbi river mouth. The coordinates of the Mdumbi wetland sites are $31^{\circ} 56^{\prime} 04 \mathrm{~S}, 29^{\circ} 12^{\prime} 41 \mathrm{E}$ and $31^{\circ} 55^{\prime} 16 \mathrm{~S}, 29^{\circ} 52^{\prime} 72 \mathrm{E}$.

\subsection{Methodology}

Six wetland sites in Mdumbi and Mngazi in catchment areas; T70B and T70G were assessed and classified to respective hydrogeomorphic units (HGM) varying between flood plain, Channeled valley bottom and unchanneled valley bottom.

For a Level 2 assessment the goods and services provided by a wetland were determined from field verifications together with the use of public consultations with the locals. The effectiveness and opportunity scores were assigned to the WET- Eco Services data spreadsheets which indicate the ability of a wetland to render goods and services [15]. Confidence rating with (marginal/low confidence $=1$ (moderate confidence $=2$, high confidence $=3$, very high confidence $=4$ was used to measure the goods and services that individual wetlands provide. Confidence scoring of all site variables; flood attenuation, stream flow regulation, sediment trapping, phosphate trapping, nitrate removal, toxicant removal, erosion control, carbon storage, education and research, tourism and recreation, cultural significance, cultivated foods, natural resources, water supply for human use, maintenance of biodiversity were obtained and compared using Independent T. Test student. Fair evaluation was defined by range of 1-2.4, and excellent evaluation was defined by range $2.5-4$. 


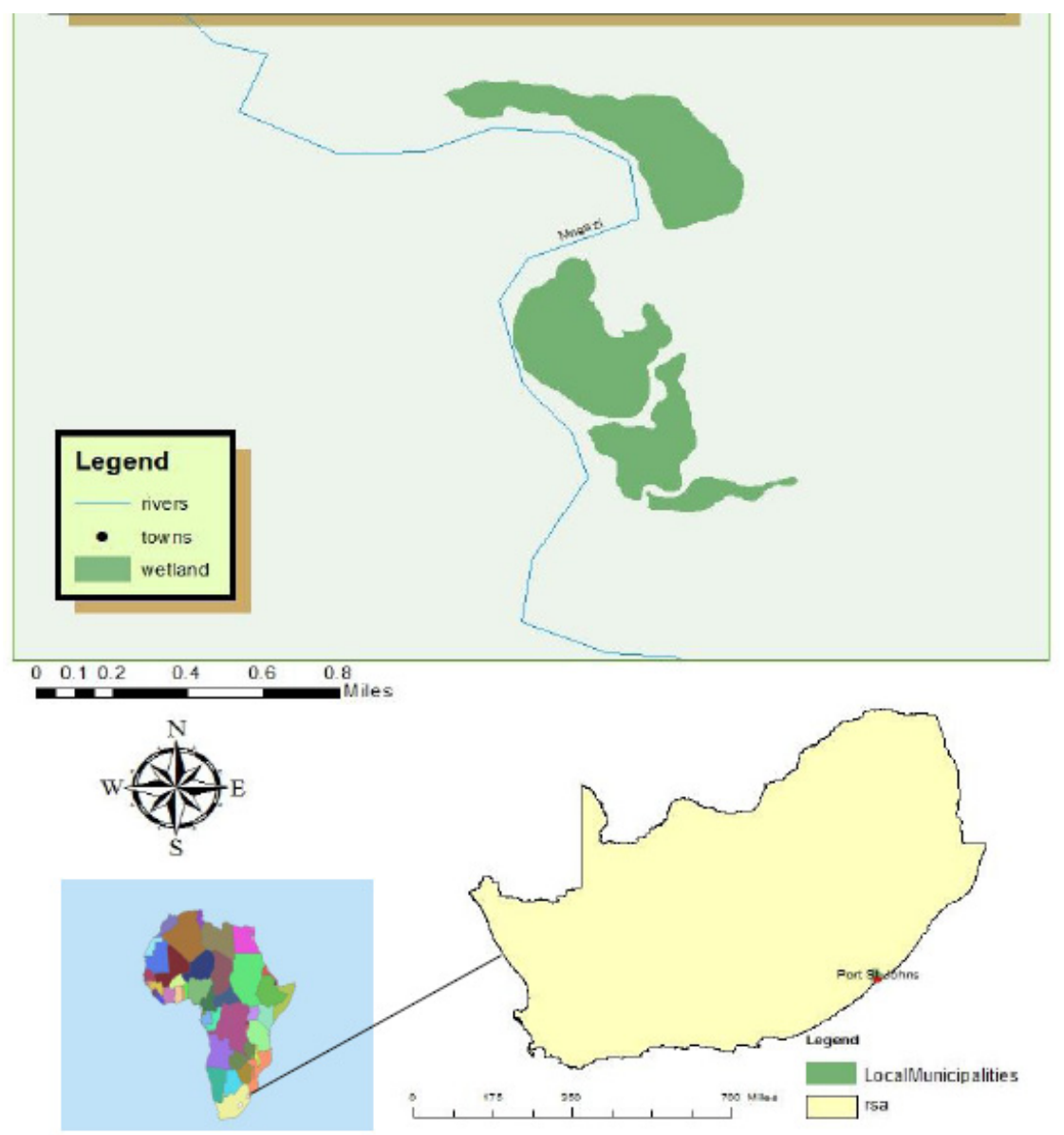

Figure 1: Map of the study sites in Port St Johns.

Questionnaires were used to facilitate public consultations and establishing the impacts that the community pose on wetlands. Three rural communities were identified along the Mngazi and four rural communities were identified along Mdumbi River and a total of 62 questionnaires were distributed in the study area respectively, 35 questionnaires were distributed in the rural communities of Vukandlule and Cwebeni surrounding Mngazi wetland sites and 27 questionnaires were distributed in Mankozi, Cwebeni and Mngcibe villages surrounding the two wetland sites in Mdumbi. These were distributed mainly to draw insight of people's understanding of wetlands and their impacts thereof and the value attached therein. 


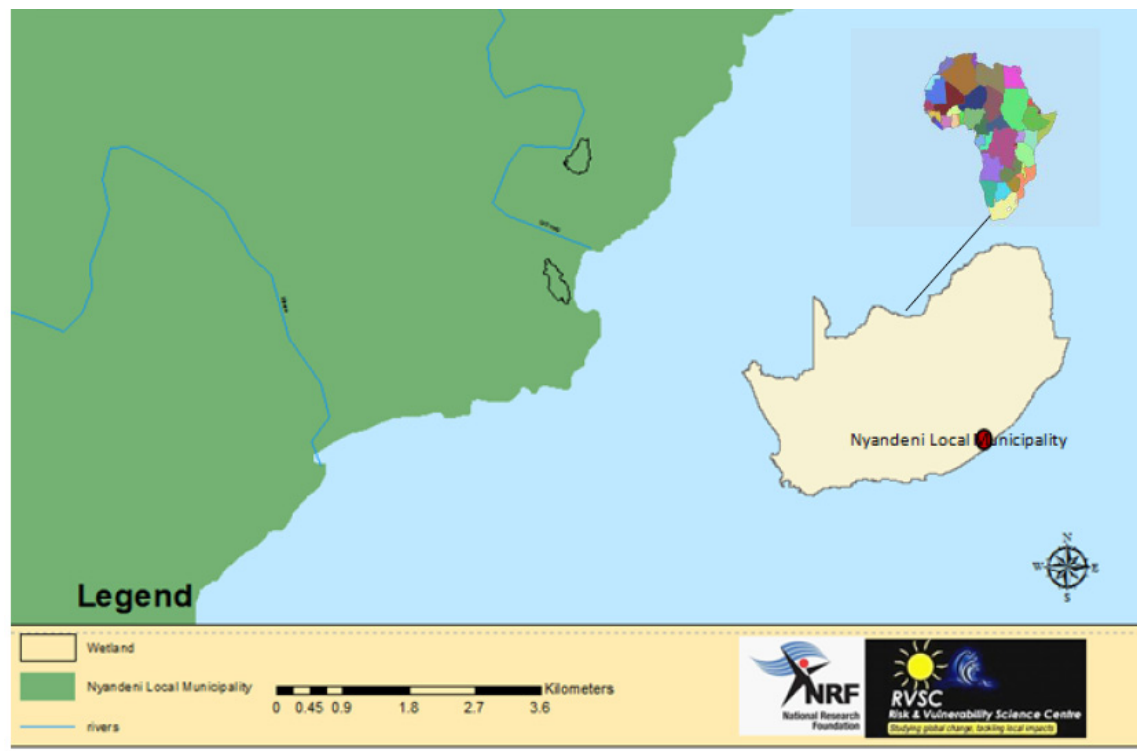

Figure 2: $\quad$ Map of the study sites in Mdumbi.

\section{Results}

The mean ecosystem services were summarized in Mngazi and Mdumbi sites by individual sites (Tables 1 and 2). For all sites the average (median) confidence rating score $(\mathrm{L}, \mathrm{MC}, \mathrm{HC}, \mathrm{VHC}$ ) were fair (low $=1$ and moderate confidence $=2$ for range 1.1-2) for flood attenuation, stream flow regulation, sediment trapping, carbon storage, maintenance of biodiversity, water supply, cultural significance, tourism and recreation, cultivated foods and education. However, the average of confidence was excellent (high confidence $=3$ and very high confidence $=4$ ) for natural resources, nitrate removal, toxicant removal and erosional control.

There was a significant variation $(\mathrm{P}<0.05)$ of all ecosystem services related to climate and pollution across Mngazi and Mdumbi wetland sites (Table 1). Compared to Mngazi sites, Mdumbi site showed the lowest confidence in flood attenuation, sediment trapping, nitrate trapping, maintenance of biodiversity, natural resources and cultivated foods. Compared to Mngazi demonstrated the lowest confidence rating in cultural significance, stream flow regulation, toxicant removal, erosional control, carbon storage, water supply for human use and education. However, the mean confidence score rating of cultural significance and water supply did not vary $(\mathrm{P}>0.05)$ between Mdumbi sites and Mngazi sites.

Table 3 shows the distribution of the respondent's frequency revealing that the largest proportion is within the age group of $21-30$ years accounting for $22.6 \%$ of the survey participants. The lowest number of participants was between the age groups of 61-70 years and 71-80 years, both accounting only for $8.1 \%$ of the survey participants. The sample of the respondents is normally distributed amongst each age category. Distribution tends to be skewed to the group of young 
Table 1: Distribution of ecosystem services scores due to climate change and pollution in all Mngazi and Mdumbi wetland sites.

\begin{tabular}{lcccc}
\hline $\begin{array}{l}\text { Variables } \\
\text { of interest }\end{array}$ & $\begin{array}{c}\text { All Median } \\
\text { Mean+SD }\end{array}$ & $\begin{array}{c}\text { Mdumbi site } \\
\text { median } \\
\text { Mean+SD }\end{array}$ & $\begin{array}{c}\text { Mngazi site } \\
\text { median } \\
\text { Mean+SD }\end{array}$ & P- value \\
\hline $\begin{array}{l}\text { Flood } \\
\text { attenuation }\end{array}$ & $1.8 \pm 0.5$ & $2.4 \pm 0.4$ & $1.5 \pm 0.4$ & $<0.001$ \\
$\begin{array}{l}\text { Stream flow } \\
\text { regulation }\end{array}$ & $2.3 \pm 0.3$ & $2.7 \pm 0.1$ & $2.1 \pm 0.1$ & $<0.001$ \\
$\begin{array}{l}\text { Sediment } \\
\text { trapping }\end{array}$ & $2 \pm 0.7$ & $2.8 \pm 0.1$ & $1.7 \pm 0.5$ & $<0.001$ \\
$\begin{array}{l}\text { Phosphate } \\
\text { trapping }\end{array}$ & $2.3 \pm 0.3$ & $2.5 \pm 0.1$ & $2.2 \pm 0.3$ & $<0.001$ \\
$\begin{array}{l}\text { Nitrate } \\
\text { removal }\end{array}$ & $2.5 \pm 0.4$ & $2.7 \pm 0.2$ & $2.3 \pm 0.3$ & $<0.001$ \\
$\begin{array}{l}\text { Toxicant } \\
\text { removal }\end{array}$ & $2.5 \pm 0.2$ & $2.3 \pm 0.2$ & $2.5 \pm 0.2$ & $<0.001$ \\
$\begin{array}{l}\text { Erosional } \\
\text { control }\end{array}$ & $2.4 \pm 0.3$ & $2.5 \pm 0.2$ & $2.4 \pm 0.3$ & 0.0016 \\
$\begin{array}{l}\text { Carbon } \\
\text { storage }\end{array}$ & $1.4 \pm 0.2$ & $1.3 \pm 0.1$ & $1.5 \pm 0.2$ & $<0.001$ \\
\hline
\end{tabular}

Table 2: Distribution of ecosystem services scores due to anthropogenic activities in all Mngazi and Mdumbi wetland sites.

\begin{tabular}{lcccc}
\hline $\begin{array}{l}\text { Variables } \\
\text { of interest }\end{array}$ & $\begin{array}{c}\text { All } \\
\text { Median } \\
\text { Mean+SD }\end{array}$ & $\begin{array}{c}\text { Mdumbi site } \\
\text { median } \\
\text { Mean+SD }\end{array}$ & $\begin{array}{c}\text { Mngazi site } \\
\text { median } \\
\text { Mean+SD }\end{array}$ & P- value \\
\hline $\begin{array}{l}\text { Maintenance of } \\
\text { biodiversity }\end{array}$ & $1.8 \pm 1$ & $1.4 \pm 0.2$ & $1.9 \pm 1.2$ & 0.019 \\
$\begin{array}{l}\text { Water supply } \\
\text { for human use }\end{array}$ & $2.1 \pm 0.9$ & $2.2 \pm 1.5$ & $2 \pm 0.1$ & 0.183 \\
$\begin{array}{l}\text { Natural } \\
\text { resources }\end{array}$ & $3.3 \pm 0.8$ & $2.5 \pm 1$ & $3.7 \pm 0.3$ & $<0.001$ \\
$\begin{array}{l}\text { Cultivated foods } \\
\begin{array}{l}\text { Cultural } \\
\text { significance }\end{array}\end{array}$ & $2.2 \pm 0.9$ & $3.3 \pm 0.2$ & $1.6 \pm 0.5$ & $<0.001$ \\
$\begin{array}{l}\text { Tourism and } \\
\text { recreation }\end{array}$ & $1.1 \pm 0.2$ & $1.2 \pm 0.2$ & $1.1 \pm 0.02$ & 0.123 \\
Education & $1.7 \pm 0.6$ & $1.4 \pm 0.4$ & $1.9 \pm 0.4$ & $<0.001$ \\
\hline
\end{tabular}

adults (below 40 years) representing approximately 54\% of the respondents. Vukandlule and Cwebeni villages in the vicinity of Mngazi wetland sites accounted for the highest representation of $40.3 \%$ as well as the lowest sample size of Cwebeni with $17.7 \%$ representation. 
Table 3: Age distribution of respondents by geographical location table.

\begin{tabular}{|c|c|c|c|c|}
\hline $\begin{array}{c}\text { Age } \\
\text { (years) }\end{array}$ & $\begin{array}{c}\text { Port St. Johns LM } \\
\text { (units of } \\
\text { measurement) }\end{array}$ & $\begin{array}{c}\text { Nyandeni LM } \\
\text { (units of } \\
\text { measurement) }\end{array}$ & n (\%) & N \\
\hline$<\mathbf{2 1}$ & 6.0 & 3.0 & 14.5 & 9 \\
\hline $\mathbf{2 1 - 3 0}$ & 6.0 & 8.0 & 22.6 & 14 \\
\hline $\mathbf{3 1 - 4 0}$ & 7.0 & 4.0 & 17.7 & 11 \\
\hline $\mathbf{4 1 - 5 0}$ & 4.0 & 5.0 & 14.5 & 9 \\
\hline $\mathbf{5 1 - 6 0}$ & 7.0 & 2.0 & 14.5 & 9 \\
\hline $\mathbf{6 1 - 7 0}$ & 3.0 & 2.0 & 8.1 & 5 \\
\hline $\mathbf{7 1 - 8 0}$ & 2.0 & 3.0 & 8.1 & 5 \\
\hline$\sum \boldsymbol{n}$ & & & & 62 \\
\hline
\end{tabular}

\subsection{Respondent's general perceptions of wetlands}

A number of the wetland uses and roles emerged from this study and they can be categorized into economical uses, recreational uses and traditional related uses. The majority of respondents consisting 14.5\% from Mngazi and Mdumbi wetland surrounding perceived the ecosystems to be bad environments promoting crime

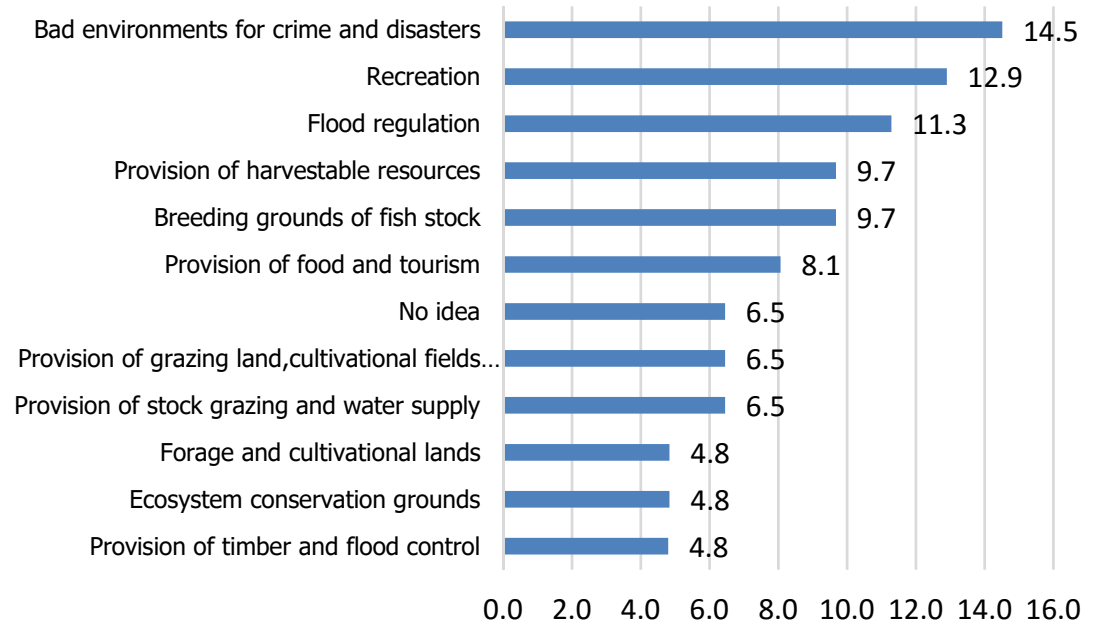

Figure 3: General perceptions of wetland ecosystems. 
and disasters. The respondents who perceived wetlands to be areas providing recreational environments consisted of $12.9 \%$ of sampled respondents. There was a steady $6.5 \%$ of the sample that maintained wetlands provided for grazing land, cultivation fields and water supply. Despite the applauded role of wetland by many, a significant $6.5 \%$ of the respondents reported that they have no idea of the role and importance of wetlands in their vicinity.

A portion of respondents consisting of $4.8 \%$ of the respondents revealed that they receive forage and cultivation lands. A slight population of $4.8 \%$ claimed to be receiving timber and flood control from the wetlands.

\section{Discussion}

The wetlands in Mngazi and Mdumbi differ in confidence rating for services due to the variations of impacts incurred. The variations from one system to another depend on the size and type of Hydrogeomorphic unit. High confidence rating was revealed in provision of natural resources and erosion control in all the wetlands of each site while moderate confidence rating was revealed for provision of erosion control, phosphate trapping, toxicant removal and nitrate removal. Low confidence rating was showed by carbon storage, cultural significance, education, tourism and recreation. The stream flow regulation, sediment trapping, maintenance of biodiversity and sediment trapping varied among wetlands with no clear pattern. In contrary, the majority of respondents perceived the wetlands as bad environments for crime and disasters. The prevalence of Acacia karoo acts as a nitrate assimilator and impacts negatively the water yields of the wetlands where it is mostly distributed [16]. The prevalence of pan drying on sections of Mngazi wetland site 3 where the species are densely distributed illustrates the impacts that Acacia karoo has on water yields of that wetland; notably on areas where the alien species are densely distributed, the wetland plants tend to decrease in distribution and terrestrial vegetation replaces the wetland vegetation.

The widely mentioned uses of wetlands by Beal [3] are present in some of the wetlands depending on the type of HGM. The mean confidence score for the capacity of the wetlands to regulate floods was 1.8. However, Acreman and Bullock [17] argue that the immediate riparian wetlands increase the response of wetlands to floods. These tend to generate higher volumes of flood flow, even if the flood peak is not increased. Also there is strong evidence that wetlands evaporate more water than any other lands such as forest and grasslands.

In conclusion, the variations in the ability of the wetlands in Mdumbi and Mngazi by our analysis of wetland ecosystem services and our field surveys are evidence that wetlands are indeed degraded by anthropogenic activities, climate change and pollution resulting to declines in wetland ability to render these services. The ability of these systems to give a quantifiable indication of services that can be rendered can provide managers with a means of determining, implementing and monitoring the ecological reserve for wetlands in rural settings which are usually not considered. There is an urgent need for conservation practices to halt the impacts posed on these wetlands, as there is evidence on the confidence ratings that these wetlands are to a certain extent able to play key roles 
of wetlands in ecosystem balancing. In terms of success of ecosystem services (ratio of fair/ excellent confidence rating was around 50\% between Mdumbi $(53.3 \%)$ and Mngazi (46.6\%).

\section{Acknowledgements}

The authors wish to acknowledge the financial assistance National Research Fund (DST/NRF) through Risk and Vulnerability Science Centre (RVSC). Help from Dr. S. Ndhleve (RSVC) and people who assisted in the study stages during data collection and analysis are noted, with thanks. We are indebted to the Division of Academic Affairs and Research Directorate for logistics support.

\section{References}

[1] Davis, T.J. (1994). The Ramsar Convention manual: A guide to the Convention on Wetlands of International Importance Especially as Waterfowl Habitat. (ed) Ramsar Convention Bureau, Gland, Switzerland.

[2] Tiner, R.W. (1991). Wetland Indicators: A Guide to Wetland Identification, Delineation, Classification and Mapping. Lewis Publishers, Boca Raton.

[3] Beal, M. (2007). An investigation of the impacts of wetlands, wetland mitigation banks, and open spaces on nearby property values, A Dissertation submitted to the Department of Economics in partial fulfilment of the requirements for the degree of Doctor of Philosophy.

[4] Kotze, D.C., Breen, C.M and Quinn, N. (1995). Wetland losses in South Africa. In: Cowen G.I (Ed), Wetlands of South Africa. Department of Environmental Affairs and Tourism, Pretoria, South Africa.

[5] Mitsch, W.J. and Gosselink, J.G. (2000). Wetlands. John Wiley, New York, USA.

[6] Begg, C. (1990). Policy Proposal for the Wetlands of Natal and Kwa-Zulu. Natal Town and Regional Planning Report, Volume 75.

[7] Ramsar Convention Bureau. (2011). The Ramsar Convention Manual: a Guide to the Convention on Wetlands (Ramsar, Iran, 1971). 4th ed. Ramsar Convention Bureau. Gland. Switzerland.

[8] Millennium Ecosystem Assessment (2000). Ecosystems and Human WellBeing: Wetlands and Waters Synthesis. World Resources Institute, Washington, DC.

[9] Nel, J.L. and Driver, A. (2011). Atlas of Freshwater Ecosystem Priority Areas in South Africa, WRC report no. TT 500/11, Water Research Commission, Pretoria, South Africa.

[10] Department of Water Affairs and Forestry (2007). Manual for the assessment of a Wetland Index of Habitat Integrity for South African floodplain and channeled valley bottom wetland types. Report no. N/0000/00/WEI/0407. Resource Quality Services, Department of Water Affairs and Forestry, Pretoria. 
[11] Kotze, D.C. (2005). Guidelines for managing wetlands in forestry areas Centre for Environment and Development. University of KwaZulu-Natal. South Africa.

[12] Nel, J., Maree, G., Roux, D., Moolman, J., Kleynhans, N., Silberbauer, M., and Driver, A. (2004). South African National Spatial Biodiversity Assessment 2004: Technical Report. Volume 2: River Component. CSIR Report No.ENV-S-I-2004-063.Council for Scientific and Industrial Research, Stellenbosch.

[13] Hulme, P.E. (2005) Adapting to climate change: is there scope for ecological management in the face of a global threat? Journal of Ecological application, 42:784-794.

[14] Drake, P., Coleman, B. and Vogwill, R. (2012). The response of semi-arid ephemeral wetland plants to flooding: linking water use to hydrological processes. Ecohydrology, DOI: 10.1002/eco.1309.

[15] Kotze, D.C., Marneweck, G.C., Batchelor, A.L., Lindley, D.S. and Collins, N.B., (2007). WET Eco Services: A technique for rapidly assessing ecosystem services supplied by wetlands. WRC Report No TT 339/08, Water Research Commission, Pretoria.

[16] Van Wilgen, B.W., de Wit, M.P., Anderson, H.J., Le Maitre, D.C., Kotze, I.M., Ndala, S., Brown, B. and Rapholo, M.B. (2004). Costs and benefits of biological control of invasive alien plants: case studies from South Africa. South African Journal of Science, 100.

[17] Acreman, M. and Bullock, A. (2003). The role of wetlands in the hydrological cycle. Centre of ecology and hydrology. Wellingford. United Kingdom. 